\title{
APLIKASI TEORI BELAJAR BERKAITAN DENGAN KEMANDIRIAN BELAJAR MAHASISWA
}

\author{
Umi Farida Hidayati $^{1 *}$, Mora Claramita ${ }^{2}$, Yayi Suryo Prabandari ${ }^{2}$ \\ 1. Akademi Keperawatan Pemerintah Provinsi Jawa Tengah, Wonosobo 56311, Indonesia \\ 2. Fakultas Kedokteran Universitas Gadjah Mada, Yogyakarta 55281, Indonesia \\ *E-mail: umifarydha@gmail.com
}

\begin{abstract}
Abstrak
Teori belajar terdiri dari teori belajar behaviourism, sosial kognitif, dan konstruktivisme. Sistem asrama merupakan pendidikan informal yang mendukung pembelajaran formal. Dengan sistem asrama, mahasiswa diharapkan dapat mandiri dalam hal belajar. Tujuan penelitian ini adalah untuk mengetahui aplikasi teori belajar di asrama berkaitan dengan kemandirian belajar mahasiswa. Penelitian ini menggunakan metode kualitatif dengan pendekatan etnografi. Subjek penelitian berjumlah 14 orang. Pengambilan data menggunakan teknik observasi dan wawancara. Hasil penelitian ini adalah aplikasi teori behaviorisme dengan adanya peraturan terkait kehidupan asrama serta adanya pelanggaran terhadap peraturan di asrama, tetapi punishment kurang tegas. Aplikasi teori sosial kognitif terlihat dominan dengan adanya pengasuh asrama yang menjadi role model, mahasiswa belajar dengan mengamati dan mencontoh, interaksi antar mahasiswa dalam belajar, pengaturan belajar sendiri oleh mahasiswa. Aplikasi teori konstruktivisme adalah pengasuh asrama memfasilitasi mahasiswa, adanya interaksi dan kolaborasi antara pengasuh asrama dan mahasiswa maupun antar mahasiswa, dan adanya pembelajaran sesuai konteks keperawatan.
\end{abstract}

Kata kunci: asrama, kemandirian belajar, teori belajar

\begin{abstract}
Application of Learning Theory related to Independent Learning of the Students. Learning theory consists of behaviorism, social cognitive and constructivism. Boarding school is an informal educational supports formal learning. With a dormitory system, students are expected to be independent in their learning process. The purpose of this study was to determine the application of learning theory related to the student learning independence. This study used a qualitative method with an ethnographic approach. There were 14 subjects. The data was collected by observation and interview techniques. The result of this research was application of the theory of behaviorism with the relevant regulations of dormitory life and a violation of the rules in the dorm, but the punishment was less firm. Application of social cognitive theory was dominant in the presence of dormitory staff as a role model, students learn by observing and imitating, the interaction between students in learning, self regulatory in learning. Application of the theory of constructivism was shown by dormitory staff facilitating to students, the interaction and collaboration between dormitory staff and student and among students and the learning context related to nursing.
\end{abstract}

Keywords: dormitory, independent learning, learning theory

\section{Pendahuluan}

Belajar adalah cara memperoleh tidak hanya skills (keterampilan) dan knowledge (pengetahuan), tetapi juga value (nilai), attitudes (sikap) dan reaksi emosional. Teori belajar yang mendasari cara seseorang belajar terdiri dari teori belajar behaviourisme, sosial kognitif, dan konstruktivisme (Ormrod, 2012; Notoatmodjo, 2010; Shephard, 2008).

Untuk mendukung peningkatan kualitas pembelajaran sebagian besar pendidikan akademi keperawatan (AKPER) di Indonesia menerapkan sistem asrama pada mahasiswa. Sistem asrama di Indonesia sudah ada sejak jaman 
dahulu (kabudan), yang disebut sebagai pondok pesantren atau pawiyatan atau asrama. Sistem asrama tersebut merupakan sistem pengajaran yang teratur dan tertib. Sistem asrama merupakan lembaga pendidikan dan pengajaran dengan paduan paling sempurna. Sistem asrama merupakan pendidikan informal yang mendukung pembelajaran. Downey (2012) menyatakan bahwa lingkungan informal mendukung lingkungan pembelajaran formal.

Akademi Keperawatan Pemerintah Provinsi Jawa Tengah (AKPER Pemprov Jateng) merupakan salah satu institusi yang mewajibkan mahasiswa tinggal di asrama dan disediakan pengasuh asrama. Kewajiban mahasiswa di asrama ini sejak tahun 2011 untuk mahasiswa tingkat pertama, sedangkan tingkat ke dua dan ke tiga diperbolehkan tidak tinggal di asrama karena keterbatasan kapasitas asrama. Dengan tinggal di asrama, mahasiswa juga diharapkan dapat mandiri, baik dalam kehidupan seharihari maupun dalam belajar.

Berdasarkan latar belakang tersebut, perlu dilakukan penelitian tentang aplikasi teori belajar berkaitan dengan kemandirian belajar mahasiswa. Tujuan penelitian ini adalah untuk mengetahui aplikasi teori belajar di asrama mahasiswa AKPER Pemprov Jateng berkaitan dengan kemandirian belajar mahasiswa.

\section{Metode}

Jenis penelitian menggunakan metode kualitatif dengan pendekatan etnografi. Populasi penelitian adalah mahasiswa AKPER Pemprov Jateng yang tinggal di asrama. Jumlah populasi penelitian sebanyak 95 mahasiswa tingkat satu dan dua. Teknik sampling yang digunakan dalam penelitian ini adalah purposive sampling. Partisi-pan yang dilibatkan dalam penelitian ini sebanyak 14 orang dengan rincian 2 mahasiswa merupakan lurah asrama, 2 mahasiswa merupakan mahasiswa dengan pengalaman tinggal di asrama, dan 9 mahasiswa merupakan mahasiswa yang tidak mempunyai pengalaman tinggal di asrama, serta 1 pengasuh asrama.
Instrumen yang digunakan dalam penelitian ini adalah pedoman observasi dan wawancara. Pelaksanaan penelitian dilakukan selama empat bulan di asrama maha-siswa AKPER Pemprov Jateng.

Pengumpulan data dilakukan dengan observasi, wawancara, dan studi dokumentasi. Analisis data dilakukan dengan langkah-langkah sebagai berikut: menentukan unit analisis data, indikasi unit yang sama dan yang berbeda, menentukan analisis domain, menentukan hubungan dan keterkaitan antar domain, membuat kesimpulan spekulatif, kesimpulan, mencari kasus negatif dan berbeda, serta menentukan teori (Afiyanti \& Rachmawati, 2014).

\section{Hasil}

Aplikasi Teori Behaviorisme. Penerapan teori behaviorism di asrama dilakukan yaitu dengan adanya peraturan-peraturan yang wajib dipatuhi oleh mahasiswa yang tinggal di asrama sesuai dengan buku panduan akademik. Hasil observasi menunjukkan beberapa pelanggaran terhadap peraturan tersebut seperti peraturan makan, peraturan meninggalkan asrama, piket asrama, dan peraturan belajar.

Sanksi terhadap pelanggaran yang dilakukan mahasiswa berupa teguran dan nasehat, misalnya mahasiswa yang seharusnya melaksanakan piket kebersihan, namun tidak melakukan ketika diingatkan, mahasiswa jadi menyadarinya. Pemberian pujian juga diberikan kepada mahasiswa misalnya dengan kata "bagus, kamu sudah kembali ke asrama", "bagus, kamu sudah berubah", "bagus, jadi contoh buat adik-adiknya ya", "besok jangan dilakukan lagi ya". Pemberian reinforcement ini mengubah perilaku mahasiswa jadi tidak melanggar atau menunjukkan perilaku lebih baik, misalnya dengan menegur jika bertemu mahasiswa lain, kembali ke asrama tepat waktu, dan lain sebagainya.

Beberapa pelanggaran cenderung ada pembiaran atau tidak mendapat sanksi yang tegas. 
Pembiaran ini juga karena berhubungan dengan senioritas. Lurah asrama putri merupakan mahasiswa tingkat 2, jika ada yang melanggar dari tingkat 3, maka lurah tidak berani menegur karena kakak kelas dianggap lebih mengetahui tentang peraturan asrama.

Sanksi terhadap pelanggaran sudah tertera dalam buku panduan mahasiswa. Sanksi yang banyak diberikan terhadap pelanggaran yang dilakukan oleh mahasiswa berupa teguran lisan dan ceramah agama. Teguran tertulis, skorsing, dan pemutusan studi tidak dilakukan karena pelanggaran yang dilakukan masih dalam kategori pelanggaran ringan-sedang. Mahasiswa juga memperlihatkan perilaku yang lebih baik ketika diberi pujian.

Aplikasi Teori Sosial Kognitif. Hasil observasi terhadap peran pengasuh asrama ditunjukkan dalam Tabel 1. Interaksi antar mahasiswa juga memengaruhi mahasiswa dalam berperilaku baik, misalnya mahasiswa belajar ketika melihat mahasiswa lain belajar. Mahasiswa menyatakan peran lingkungan dan teman sangat berpengaruh terhadap dirinya dalam perilaku belajar di asrama. Mahasiswa juga menyata- kan lebih merasa termotivasi oleh teman atau kakak kelas. Kamar asrama diatur terdiri dari mahasiswa tingkat 1,2 dan 3, dan interaksi mahasiswa dengan teman sekamar juga baik bahkan lebih nyaman karena ada kakak kelas yang dapat membantu dalam penyelesaian tugas.

Perilaku belajar mahasiswa terlihat ketika sedang mengerjakan tugas bersama-sama. Waktu yang dijadwalkan adalah pukul 19.30 sampai 21.30 setiap malam, tetapi sedikit mahasiswa yang memanfaatkan jam belajar tersebut karena mahasiswa belajar di waktu lain misalnya malam hari, dini hari atau pagi hari. Pemanfaatan jam belajar digunakan untuk mengerjakan tugas secara berkelompok.

Aplikasi Teori Konstruktivisme. Pengasuh asrama berperan memfasilitasi mahasiswa penghuni asrama selama mahasiswa praktik klinik. Pengasuh asrama mempunyai jadwal praktik sehingga mudah mengontrol dan mengkoordinasi mengenai jam keluar masuk asrama dan makan. Pengasuh asrama juga bekerja sama dengan mahasiswa dalam menyiapkan kegiatan keagamaan, seperti kegiatan di bulan Ramadhan,

Tabel 1. Hasil observasi tugas pengasuh asrama

\begin{tabular}{|c|c|c|}
\hline No & Tugas & Hasil Observasi \\
\hline 1 & $\begin{array}{l}\text { Memantau dan membimbing tertibnya } \\
\text { peraturan asrama }\end{array}$ & $\begin{array}{l}\text { 1) Pengasuh asrama melaksanakan apel tiap minggu malam } \\
\text { 2) Pengasuh asrama mendampingi rapat mahasiswa tiap bulan }\end{array}$ \\
\hline 2 & $\begin{array}{l}\text { Membimbing mahasiswa untuk mempunyai } \\
\text { akhlak dan sikap professional perawat melalui }\end{array}$ & $\begin{array}{l}\text { 3) Pengasuh asrama mengontrol mahasiswa yang sedang } \\
\text { praktik dengan mempunyai jadwal praktik }\end{array}$ \\
\hline & kehidupan asrama & 4) Pengasuh asrama menelpon mahasiswa yang tidak kembali \\
\hline 3 & Memfasilitasi kegiatan asrama & ke asrama selam 3 hari dan melakukan terguran lisan \\
\hline 4 & $\begin{array}{l}\text { Membantu dan mendukung kelancaran } \\
\text { pembelajaran di asrama }\end{array}$ & $\begin{array}{l}\text { 5) Pengasuh asrama tidak menegur mahasiswa yang } \\
\text { membawa makanan ke kamar, menonton televisi ketika jam }\end{array}$ \\
\hline 5 & $\begin{array}{l}\text { Menegakkan kedisiplinan, keamanan, } \\
\text { ketertiban dan keindahan di lingkungan } \\
\text { asrama }\end{array}$ & $\begin{array}{l}\text { belajar, } \\
\text { 6) Pengasuh asrama memberikan contoh dan secara bersama- } \\
\text { sama melakukan kerja bakti }\end{array}$ \\
\hline 6 & $\begin{array}{l}\text { Memonitor terpenuhinya kebutuhan asrama } \\
\text { untuk P3K, kebersihan, dan pemenuhan nutrisi }\end{array}$ & $\begin{array}{l}\text { 7) Pengasuh asrama mendampingi mahasiswa dalam kegiatan } \\
\text { di asrama (yasinan, tarawih, tadarusan) }\end{array}$ \\
\hline 7 & $\begin{array}{l}\text { Berkoordinasi dengan seksi kemahasiswaan } \\
\text { dalam rangka pembinaan sikap dan perilaku }\end{array}$ & $\begin{array}{l}\text { 8) Pengasuh asrama mengingatkan untuk menjaga kebersihan } \\
\text { asrama dan etika menerima tamu. }\end{array}$ \\
\hline & mahasiswa & $\begin{array}{l}\text { 9) Pengasuh asrama memfasilitasi mahasiswa dalam kegiatan } \\
\text { akademi, pendataan fasilitas asrama yang rusak, } \\
\text { 10) Pengasuh asrama koordinasi dengan mahasiswa dan } \\
\text { penanggungjawab asrama terkait dengan pergantian kamar. }\end{array}$ \\
\hline
\end{tabular}


Tabel 2. Hasil penelitian

\begin{tabular}{|c|c|c|}
\hline No & Teori & Hasil \\
\hline 1 & $\begin{array}{l}\text { Teori } \\
\text { behaviorisme }\end{array}$ & $\begin{array}{l}\text { 1) Ada peraturan asrama yang wajib dipatuhi } \\
\text { 2) Ada pelanggaran terhadap peraturan makan, meninggalkan dan kembali ke asrama, } \\
\text { kebersihan lingkungan asrama, dan jam belajar } \\
\text { 3) Punishment berupa teguran dan nasihat } \\
\text { 4) Ada sistem reinforcement, tetapi tidak dominan } \\
\text { 5) Mahasiswa menunjukkan perubahan perilaku ketika diberi punishment dan } \\
\text { reinforcement }\end{array}$ \\
\hline 2 & $\begin{array}{l}\text { Teori sosial } \\
\text { kognitif }\end{array}$ & $\begin{array}{l}\text { 1) Mahasiswa belajar dengan mengamati dan mencontoh } \\
\text { 2) Ada pengasuh asrama sebagai role model } \\
\text { 3) Interaksi antar penghuni asrama memengaruhi perilaku mahasiswa } \\
\text { 4) Lingkungan/teman berpengaruh dalam perilaku mahasiswa } \\
\text { 5) Mahasiswa mempunyai pengaturan belajar sendiri walaupun ada peraturan jam belajar }\end{array}$ \\
\hline 3 & $\begin{array}{l}\text { Teori } \\
\text { konstruktivisme }\end{array}$ & $\begin{array}{l}\text { 1) Pengasuh asrama memfasilitasi mahasiswa selama di asrama mengenai fasilitas, } \\
\text { kegiatan dan etika tetapi tidak dalam belajar } \\
\text { 2) Interaksi dan kerjasama antar mahasiswa dalam kegiatan kampus dan belajar selama di } \\
\text { asrama } \\
\text { 3) Ada pembelajaran sesuai dengan konteks ilmu keperawatan (misalnya asuhan } \\
\text { keperawatan), sikap (peduli, disiplin, tanggung jawab, sopan santun) }\end{array}$ \\
\hline
\end{tabular}

melaksanakan kerja bakti kebersihan asrama, rolling kamar, pendataan fasilitas asrama yang rusak/ perlu diganti, senam pagi, dan ketika mahasiswa mengalami masalah dalam kegiatan kampus. Pengasuh asrama juga berkoordinasi dengan pihak lain yang terkait, selain dengan mahasiswa. Mahasiswa tidak segan untuk meminta pendapat dari pengasuh asrama.

Pengasuh asrama juga memberi pengarahan tentang etika masuk kamar, menyapa ketika bertemu, berpenampilan sopan dan rapi, menjaga sopan santun, memiliki rasa sosial yang tinggi, berinteraksi dengan lingkungan sekitar, mengikuti kegiatan kampus dan menjaga fasilitas asrama dan kampus.

Interaksi dan kerjasama antar mahasiswa juga terlihat ketika mahasiswa menyiapkan kegiatan kampus, mengerjakan tugas berkelompok sehingga jika ada kesulitan mahasiswa bisa berdiskusi, kegiatan olahraga di sore hari setelah perkuliahan, dan seni musik. Kakak kelas juga memfasilitasi adik kelas dalam kehidupan asrama seperti yang dinyatakan oleh mahasiswa sebagai berikut: “...iya disini kadang tu kamu tuh di asrama tapi ga pernah ngobrol sama mbak-mbaknya tetapi mbak-mbaknya malah peduli jadi enak rasanya mereka tu malah nganggep kita kayak temennya gitu lho bu seiring berjalannya waktu saya mulai akrab dengan mbak-mbaknya terus saya juga diajarin ini lho perjuangannya kalau kita mau kegiatan ya ini perjuangannya ini lho kepanitiannya."

“... sosialisasi dengan teman sekarang meningkat lagi karena baru sama adikadiknya. mereka mbok kamu gini tapi mereka juga nglakuin."

Mahasiswa juga berbagi tentang pengetahuan, baik pengetahuan dalam konteks ilmu keperawatan atau pengetahuan dan keterampilan lainnya, misalnya penyusunan tugas akhir, atau aplikasi komputer. Mahasiswa pun belajar dari tugas perkuliahan yang telah dilakukan dan pengalaman dari kakak kelas.

“..mereka kadang saya tanya tentang pelajaran mereka langsung kasih tau kalau minta contoh tugas/ askep kok ga dari 
kemarin disini satu minggu dua minggu tu ternyata mbak-mbaknya baik-baik."

Mahasiswa lebih rajin dan semangat dalam belajar di asrama karena pengaruh lingkungan asrama, yaitu pengaruh teman, adanya fasilitas, motivasi dari teman dan kakak kelas, dan adanya persaingan antar penghuni asrama dan mahasiswa bisa berdiskusi baik dengan teman maupun dari kakak kelas. Secara umum, aplikasi teori belajar di asrama digambarkan dalam Tabel 2.

\section{Pembahasan}

Penggunaan aturan merupakan salah satu hal yang penting dalam mendukung proses kemandirian, terutama dalam menentukan yang benar dan yang salah (Benson \& Grove, 1998). Penerapan teori behaviorisme di asrama AKPER Pemprov Jateng yaitu adanya peraturan yang wajib dipatuhi oleh mahasiswa yang tinggal di asrama sesuai dengan buku panduan akademik. Hal ini didukung penelitian Saomah (2006) menunjukkan bahwa pada awalnya bentuk kepatuhan itu karena dikontrol oleh pembina asrama. Namun, seiring dengan lamanya waktu tinggal di asrama serta kematangan remaja itu sendiri, proses kepatuhan itu berkembang menjadi sesuatu yang diputuskan dan dikontrol oleh diri sendiri sehingga siswa bisa menjadi mandiri.

Dalam proses operant conditioning, ada yang disebut dengan punishment/ hukuman, yaitu stimulus yang jika diberikan pada suatu respon akan menurunkan kemungkinan respon tersebut muncul kembali (Ormrod, 2012). Dari hasil observasi didapatkan terdapat pelanggaran terhadap peraturan tersebut seperti peraturan makan, peraturan meninggalkan asrama, piket asrama, dan peraturan belajar. Pelanggaran yang dilakukan mahasiswa termasuk dalam kategori ringan sampai sedang. Pelanggaran-pelanggaran yang dilakukan mahasiswa di asrama putra dan putri kurang terkontrol baik oleh lurah asrama maupun pengasuh asrama. Pelanggaran tersebut cenderung ada pembiaran atau tidak adanya sanksi yang tegas terhadap pelanggaran yang dilakukan. Sanksi terhadap pelanggaran yang dilakukan mahasiswa berupa teguran lisan dan nasehat, misalnya mahasiswa melaksanakan piket kebersihan ketika diingatkan, mahasiswa jadi lebih ramah kepada yang lain ketika diberi nasehat. Hal ini didukung Dewantara (2013) yang menyatakan bahwa dalam sebuah pendidikan tidak menggunakan paksaan, tidak juga dengan pembiaran, tetapi perlu memperhatikan perilaku siswa agar sesuai. Salah satu peralatan pendidikan berupa perintah, paksaan dan hukuman, tetapi banyak yang tidak setuju dengan metode tersebut.

Dalam operant conditioning perilaku dapat "dibentuk" (shaping) melalui penggunaan reinforcement yang tepat. Skinner menjelaskan bahwa reinforcement adalah elemen kunci dalam teori operant conditioning, yang dapat mengakibatkan perilaku tersebut berulang kembali atau menghilang sesuai keinginan (Ormrod, 2012). Dalam penelitian ini, mahasiswa juga memperlihatkan perilaku yang lebih baik ketika diberikan pujian. Pemberian reinforcement ini mengubah perilaku mahasiswa menjadi tidak melanggar atau menunjukkan perilaku yang lebih baik, misalnya dengan bertegur sapa jika bertemu mahasiswa lain, kembali ke asrama tepat waktu, dan lain sebagainya. Hal ini sesuai dengan penelitian Mendari (tahun) yang bahwa konsep motivasi belajar berkaitan erat dengan prinsip bahwa memperoleh reinforcement/penguatan dibandingkan dengan perilaku yang tidak mendapat penguatan atau perilaku yang terkena hukuman (punishment). Pemberian reinforcement dapat disimpulkan lebih efektif terhadap perubahan perilaku dibandingkan dengan punishment (Mendari, 2010).

Seorang role model mempunyai kompetensi sebagai seorang perawat. Model mempunyai juga mempunyai kebanggan dan kekuatan, dan berperilaku sesuai dengan gender dan relevan dengan situasi pembelajar (Ormrod, 2012). Role model di asrama putri pengasuh asrama putri yang juga merupakan seorang perawat yang pernah mempunyai pengalaman tinggal di asrama. Kondisi ini kurang sejalan dengan hasil 
penelitian Qodir (2004) di pondok pesantren. Tokoh sentral yang menjadi teladan atau role model diasrama putera di pondok pesantren adalah Kyai.

Individu belajar dengan cara mengamati. Cara ini merupakan perwujudan dari pendidikan dengan cara memberikan contoh perilaku bagi siswa (Ormrod, 2008). Hal ini sesuai dengan hasil penelitian ini. Pengasuh asrama memberikan contoh berupa tindakan nyata kepada mahasiswa, dengan cara melaksanakan kerja bakti kebersihan, kegiatan keagamaan, dan senam pagi.

Social Cognitive Theory (SCT) menggambarkan perilaku dan fungsi manusia sebagai hasil dari kedinamisan hubungan antar individu, tindakan individu dan lingkungannya, yang disebut dengan triadic reciprocal causation (Bandura, 2004; Ormrod, 2008, 2009). Dalam penelitian ini, interaksi antara mahasiswa dengan mahasiswa lain juga memengaruhi mahasiswa dalam berperilaku baik dalam hal positif maupun negatif, misalnya mahasiswa belajar ketika melihat mahasiswa lain belajar. Mahasiswa menyatakan peran lingkungan dan teman sangat berpengaruh terhadap dirinya dalam perilaku belajar di asrama. Mahasiswa lebih rajin dan semangat dalam belajar di asrama karena adanya pengaruh lingkungan, yaitu lingkungan asrama, pengaruh teman, adanya fasilitas, motivasi dari teman dan kakak kelas, dan adanya persaingan antar penghuni asrama. Hal ini sesuai dengan pernyataan Soekanto (2005), yang menyatakan bahwa faktor-faktor yang memengaruhi interaksi sosial adalah imitasi, identifikasi, sugesti dan simpati.

Menurut Bandura, individu mempunyai kemampuan dasar self regulatory yang merupakan pusat dari pengembangan individu. Banyak tindakan individu diatur oleh standar internal dan tindakan evaluatif dari tindakan yang dilakukan (Ormrod, 2009). Dalam penelitian ini, perilaku belajar mahasiswa terlihat ketika sedang mengerjakan tugas bersama-sama. Waktu yang dijadwalkan adalah pukul 19.30 - 21.30 setiap malam, tetapi sedikit mahasiswa yang memanfaatkan jam belajar tersebut karena mahasiswa belajar di waktu lain misalnya malam hari, dini hari atau pagi hari. Pemanfaatan jam belajar digunakan untuk mengerjakan tugas secara berkelompok. Mahasiswa jarang memanfaatkan jam belajar tersebut karena pada jam tersebut suasana asrama ramai sehingga kurang kondusif untuk belajar. Dengan kondisi asrama tersebut, mahasiswa mempunyai pengaturan belajar sendiri di luar jam belajarnya. Mahasiswa jarang memanfaatkan perpustakaan karena mahasiswa kurang menyukai belajar dari buku tetapi lebih menyukai belajar dari internet. Perlu penjelasan tambahan krn saat ini metode pembelajaran online telah diterapkan dalam proses pembelajaran SCL. Hal ini juga sesuai dengan penelitian Afifah (2007) yang memperlihatkan bahwa semua responden mengakses internet untuk kegiatan pembelajaran.

Aplikasi Teori Konstruktivisme. Menurut surat tugas pengasuh asrama, pengasuh asrama mempunyai tugas memfasilitasi kegiatan di asrama, membantu dan mendukung kelancaran pembelajaran di asrama. Hasil penelitian menunjukkan pengasuh asrama mempunyai peran memfasilitasi mahasiswa selama di asrama, yaitu selama mahasiswa praktik klinik, pengasuh asrama mempunyai jadwal praktik sehingga mudah mengontrol dan mengkoordinasi mengenai jam keluar masuk asrama dan makan. Pengasuh asrama juga memfasilitasi kegiatan di asrama seperti kegiatan ramadhan, melaksanakan kerja bakti kebersihan asrama, kegiatan keagamaan, rolling kamar, pendataan fasilitas asrama yang rusak/perlu diganti, menyediakan fasilitas obat-obatan Pertolongan Pertama Pasa Kecelakaan (P3K), senam pagi dan ketika mahasiswa mengalami masalah dalam kegiatan kampus. Hal ini sesuai dengan penelitian Yue, et al. (2012) yang menyatakan bahwa tanggung jawab pengelola asrama adalah manajemen asrama, keamanan siswa, logistik, serta kesehatan fisik dan psikologis. Pengelola juga memperhatikan siswa setelah pembelajaran di kelas selesai, melatih cara berdisiplin dan komunikasi efektif dengan siswa lain, serta menerapkan 
pola tidur yang baik dan perilaku sehat dan mengenali penyakit siswa yang umum terjadi.

Pengasuh asrama juga bekerjasama dan bekerjasama dengan mahasiswa dalam menyiapkan kegiatan Ramadhan, melaksanakan kerja bakti kebersihan asrama, kegiatan keagamaan, rolling kamar, pendataan fasilitas asrama yang rusak/perlu diganti, senam pagi dan ketika mahasiswa mengalami masalah dalam kegiatan kampus, pengasuh asrama juga bisa langsung berkoordinasi dan mahasiswa meminta pendapat dari pengasuh asrama.

Interaksi dan kolaborasi antar mahasiswa juga terlihat ketika mahasiswa menyiapkan kegiatan kampus secara bersama-sama, mengerjakan tugas berkelompok, sehingga jika ada kesulitan mahasiswa bisa berdiskusi, kegiatan olahraga di sore hari setelah perkuliahan, dan seni musik. Mahasiswa lebih rajin dan semangat dalam belajar di asrama karena pengaruh lingkungan asrama, yaitu pengaruh teman, adanya fasilitas, motivasi dari teman dan kakak kelas, dan adanya persaingan antar penghuni asrama dan mahasiswa bisa berdiskusi baik dengan teman maupun dari kakak kelas. Salah satu prinsip teori konstruktivisme adalah adanya interaksi sosial yang berperan penting dalam pengembangan pemahaman mahasiswa. Pembelajaran efektif dengan bekerjasama dengan yang lain pada saat menyelesaikan tugas yang tidak dikerjakan sendiri (Cantilon \& Wood, 2010). Interaksi sosial di asrama terlihat pada saat mahasiswa berkumpul menonton televisi, sekedar berkunjung di kamar, meminjam barang, meminjam buku, tugas, dan lain sebagainya. Hal ini sesuai dengan Soekanto yang menyatakan interaksi sosial terjadi jika ada 2 syarat, yaitu adanya kontak sosial dan komunikasi sosial (Soekanto, 2005).

Belajar sesuai konteks mendukung kemampuan pembelajar untuk digunakan pada masa yang akan datang (Dornan, et al., 2011). Dalam penelitian ini, mahasiswa juga berbagi tentang ilmu baik dalam konteks ilmu keperawatan maupun ilmu lain misalnya penyusunan tugas akhir, komputer, tugas dan pengalaman kakak kelas. Mahasiswa juga belajar berperilaku yang sesuai dengan perawat seperti kedisiplinan, komunikasi, interaksi dan peduli dengan orang lain, bertanggungjawab terhadap diri dan lingkungannya. Hal ini sesuai dengan penelitian Yue, et al. (2012) yang menyatakan bahwa tanggung jawab pegelola asrama adalah memperhatikan siswa setelah pembelajaran di kelas selesai, melatih cara berdisiplin dan komunikasi efektif dengan siswa lain.

Steinberg menyatakan beberapa alasan yang mendukung pencapaian prestasi yang lebih baik dari remaja yang mandiri itu antara lain: memiliki motivasi intrinsik yang lebih tinggi dalam belajar, mampu menggunakan sumbersumber pribadi dan sumber yang diberikan dari institusi tempat belajar secara lebih baik, mampu melaksanakan pembelajaran mereka dalam suatu cara yang independent (Mendari, 2010). Mahasiswa yang tinggal di asrama mahasiswa AKPER Pemprov Jawa Tengah telah dibekali aturan tentang jam belajar, tetapi mahasiswa kurang memanfaatkan kesempatan ini karena mahasiswa mempunyai pengaturan sendiri. Hal ini sesuai dengan teori sosial kognitif yang menyatakan bahwa individu mempunyai kemampuan dasar self regulatory yang merupakan pusat dari pengembangan individu. Banyak tindakan individu diatur oleh standar internal dan tindakan evaluatif dari tindakan yang dilakukan (Ormrod, 2009).

\section{Kesimpulan}

Teori belajar yang dominan dan mendukung kemandirian belajar mahasiswa di asrama adalah teori sosial kognitif. Bagi sekolah berasrama disarankan menyediakan pengasuh asrama sebagai role model dan fasilitator kehidupan di asrama untuk mendukung pembelajaran. Progam mentoring dari kakak kelas dapat dilakukan untuk mempercepat adaptasi mahasiswa baru, menetralisir adanya senioritas serta kontrol perilaku mahasiswa. Untuk mendukung proses pembelajaran di asrama, perlu dukungan lingkungan yang kondusif. Oleh karena itu, di- 
perlukan manajemen yang mampu menjaga komitmen seluruh staf yang terlibat (SR, AYN, INR).

\section{Referensi}

Afifah, E. (2007). Faktor-faktor yang berhubungan dengan pemanfaatan internet sebagai sarana pencarian informasi pembelajaran pada mahasiswa keperawatan. Jurnal Keperawatan Indonesia, 11 (2), 41-46.

Afiyanti, Y., \& Rachmawati, I.N. (2014). Metodologi penelitian kualitatif dalam riset keperawatan. Jakarta: Raja Grafindo.

Bandura, A. (2004). Health promotion by social cognitive means. Health Educational Behavior, 31, 143-164.

Benson, N.C., \& Grove, S. (1998). Psychology for Beginners. Crambidge: Icon Books Ltd.

Cantilon, P., \& Wood, D. (2010). ABC of learning and teaching in medicine (2nd Ed.). London: Wiley-Blackwell.

Dewantara, K.H. (2013). Karya Ki Hadjar Dewantara bagian pertama: Pendidikan. Yogyakarta: Majelis Luhur Persatuan Tamansiswa.

Downey, A. (2012). Formal and informal learning environments. University of North Texas.

Mendari, AS. (2010). Aplikasi teori hierarki kebutuhan Maslow dalam meningkatkan motivasi belajar mahasiswa. Widya warta, 1 (34), 82-91.
Notoatmodjo, S. (2010). Ilmu perilaku kesehatan. Jakarta: Rineka Cipta.

Ormrod, J.E. (2008). Psikologi pendidikan, membantu siswa tumbuh dan berkembang (Jilid 1, Edisi 6). Jakarta: Erlangga.

Ormrod, J.E. (2009). Psikologi pendidikan, membantu siswa tumbuh dan berkembang. Jilid 2. Edisi 6. Jakarta: Erlangga.

Ormrod, J.E. (2012). Human learning (6th Ed.) One Lake Street, Upper Saddle River, New Jersey: Pearson Education Inc.

Qodir, A. (2004). Pembaharuan sistem pendidikan pesantren dalam pembentukan kemandirian santri. Jurnal Studi Agama dan Masyarakat, $1(1), 55-72$.

Saomah, A. (2006). Hubungan antara gaya pengasuhan orangtua authoritative, authoritari$a n$, indulgent, dan indifferent dengan $k e-$ mandirian siswa (Tesis, Tidak dipublikasi). Program Pascasarjana Universitas Padjadjaran, Bandung.

Shephard, K. (2008). Higher education for sustainability: seeking affective learning outcomes. International Journal of Sustainability in Higher Education, 9 (1), 87 98.

Soekanto, S. (2005). Sosiologi suatu pengantar. Jakarta: Raja Grafindo Persada.

Yue, A., Shi, Y., Chang, F., Yang, C., Wang, H., Yi, H., et al. (2012). Dormitory management and boarding students in china's rural elementary schools. Rural Education Action Project. Diperoleh dari http://fsi.stanford.edu/ 